\title{
PENDAPAT HAKIM PA BANGKALAN DAN PA SIDOARJO MENGENAI STATUS ANAK LUAR KAWIN
}

\author{
Siti Dalilah Candrawati \\ Fakultas Syariah dan Hukum UIN Sunan Ampel Surabaya \\ E-mail: dalilah@uinsby.ac.id
}

\begin{abstract}
This paper is the result of a field research on the opinion of the judges of $P A$ (Religious Church) Bangkealan and Sidoarjo against the MK's decision No. 46/PUU-VIII/2010. The MK's decision is important from the point of view of judge as the law enforcement because it invites a lot of debate in the community. In this research, the author collects data using interview and documentation technique. The collected data is then analyzed by using descriptive-verification technique to describe the opinion of the judges of the MK's decision No. 46/PUU-VIII/2010. The finding of the study is that the judges of $P A$ interpret the child outside of marital contract includes: a child born by a woman who is not tied to marriage with a man who impregnates her, a child resulted from a sirri marriage, a child born from the infidelity of either within the marital period or not, a child resulted from a living together (samen liven), a child as a result of being raped by a man or more, a child who legally denied by his father, a child as a result of a wrong sexual intercourse, a child born out of a fasid marriage, and a child born from a surrogate mother. The judges of $P A$ also have different opinion about the MK's decision No. 46/PUU-VIII/2010 on the legal status of a child born outside of a marital contract. There are four kinds of view: the MK's decision is legally flawed, the MK's decision needs a new setting, the MK's decision has a limited effect on a materially child's civil right, the MK's decision has the absolute force as the first and the last constitutional court decision. Therefore, it has a legal implication for the child to his mother and father based on science and technology and/or other evidence justified by law as to have a blood relationship between a child and his biological father.
\end{abstract}

Abstrak: Tulisan ini merupakan hasil penelitian lapangan yang melihat pendapat hakim PA Bangkalan dan Sidoarjo terhadap putusan MK No. 46/PUU-VIII/2010. Putusan MK tersebut, penting dilihat dari sudut pandang hakim sebagai pelaksana hukum karena mengundang banyak polemik di kalangan masyarakat. Untuk itu, penulis mengumpulkan data menggunakan teknik wawancara dan dokumentasi. Data yang terkumpul kemudian dianalisis menggunakan teknik deskriptif-verifikatif untuk menggambarkan pendapat hakim tentang putusan MK No. 46/PUUVIII/2010. Dengan metode tersebut, penelitian ini menemukan, bahwa para hakim PA menginterpretasikan anak luar perkawinan meliputi: anak lahir dari perempuan yang tidak terikat perkawinan dengan laki-laki yang 
menghamili, anak hasil perkawinan sirri, anak lahir dari perselingkuhan baik perempuan terikat perkawinan atau tidak, anak hasil hidup bersama (samen liven), anak lahir akibat diperkosa oleh seorang laki-laki atau lebih, anak lahir yang diingkari (dili'an) ayahnya, anak lahir akibat hubungan seks salah orang/ salah sangka, anak lahir akibat perkawinan yang $f a>$ sid/ batal, dan dimungkinkan anak lahir dari ibu pengganti (surrogate mother). Para hakim PA juga memiliki pendapat yang berbeda mengenai putusan MK No 46/PUU-VIII/2010 yang mengatur status hukum anak yang dilahirkan di luar perkawinan. Ada empat macam pandangan: putusan MK cacat yuridis, putusan MK perlu pengaturan baru, putusan MK berlaku terbatas pada hak perdata anak yang bersifat materiil, putusan MK mutlak berlaku karena merupakan putusan perkara konstitusi tingkat pertama dan terakhir, karenanya berimplikasi pada hubungan perdata anak selain dengan ibunya juga dengan ayahnya berdasarkan ilmu pengetahuan dan tehnologi dan/atau bukti lain yang dibenarkan oleh hukum memiliki hubungan darah antara anak dengan ayah biologisnya.

Kata Kunci: Pendapat hakim, putusan MK, dan anak luar kawin

\section{Pendahuluan}

Putusan Mahkamah Konstitusi Nomor 46/PUU-VIII/2010 atas perkara permohonan pengujian materi pasal 2 ayat (2) dan pasal 43 ayat (1) Undang-Undang Nomor 1 Tahun 1974 Tentang Perkawinan terhadap pasal $28 \mathrm{~B}$ ayat $(1,2)$ dan pasal $28 \mathrm{D}$ ayat (1) Undang-Undang Dasar Negara Republik Indonesia Tahun 1945, telah mengabulkan sebagian permohonan $\mathrm{Hj}$. Aisyah Mochtar alias Machicha binti $\mathrm{H}$ Mochtar Ibrahim dan putranya Muhammad Iqbal Ramadlan bin Moerdiono yang disampaikan dalam sidang pleno Mahkamah Konstitusi pada hari Jum'at tanggal 17 Pebruari 2012, yaitu perubahan atas bunyi pasal 43 ayat (1) Undang-undang No 1 tahun 1974.

Dalam amar putusan MK dinyatakan, bahwa rumusan pasal 43 ayat (1) Undang-Undang Nomor 1 Tahun 1974 yang menyatakan "Anak yang dilabirkan di luar perkawinan banya memiliki bubungan perdata dengan ibunya dan keluarga ibunya", tidak memiliki kekuatan hukum mengikat sepanjang dimaknai menghilangkan hubungan perdata dengan laki-laki yang dapat dibuktikan berdasarkan ilmu pengetahuan dan tehnologi dan/atau alat bukti lain menurut hukum ternyata mempunyai hubungan darah sebagai ayahnya, sehingga ayat tersebut harus dibaca "Anak yang dilabirkan di luar perkawinan mempunyai bubungan perdata dengan ibunya dan 
keluarga ibunya yang dapat dibuktikan berdasarkan ilmu pengetabuan serta tehnologi dan/atau alat bukti lain menurut bukum mempunyai bubungan darah dengan ayah biologisnya".

Putusan Mahkamah Konstitusi yang mengadili perkara konstitusi pada tingkat pertama dan terakhir di atas membawa akibat pada perombakan hukum keluarga Indonesia secara signifikan. Hukum positif selama ini menempatkan status hukum anak di luar kawin berbeda dengan anak sah. Anak luar kawin diperlakukan secara berbeda karena hanya memiliki hubungan perdata dengan ibunya dan keluarga ibunya, yang berarti tidak memiliki hubungan perdata dengan ayah maupun keluarga ayahnya. Sesudah Putusan MK, anak dipandang memiliki hubungan perdata selain dengan ibunya dan keluarga ibunya juga dengan ayah biologisnya dan keluarga ayahnya.

Keputusan yang didukung oleh para pegiat perlindungan hak anak itu menimbulkan komentar, pendapat dan polemik yang cukup memanas dari para tokoh Islam. Mimbar shalat jum'at pun digunakan khatib untuk mengecam putusan trobosan ini, meskipun khotbah monolog ini tidak menyelesaikan masalah, bahkan bisa meresahkan tanpa solusi. Sebagian tokoh Islam yang menolak adalah Majelis Ulama Indonesia (MUI). Dalam tanggapannya atas putusan MK tersebut, Majelis Ulama Indonesia (MUI) menyatakan, bahwa putusan MK No 46/PUU-VIII/2010 sepanjang memaknai pengertian "hubungan perdata" antara anak hasil zina dengan laki-laki yang mengakibatkan kelahirannya dan keluarganya adalah juga hubungan nasab, waris, wali, dan nafaqah, maka putusan MK tersebut bertentangan dengan ajaran Islam. Namun demikian, dalam system hukum nasional yang tidak mengenal upaya hukum bagi putusan MK, mengingat dampak yang ditimbulkan oleh putusan MK tersebut sangatlah besar, maka MUI tetap meminta agar MK melakukan peninjauan kembali terhadap putusannya tersebut demi kemaslahatan kehidupan berbangsa dan bernegara yang lebih besar urgensinya .

Berbeda dengan tanggapan MUI yang menolok Putusan MK tersebut, dalam kajian Majlis Tarjih Muhammadiyah Jawa Timur, dalam sebuah agenda kajian ilmiah menyatakan, bahwa hukum Islam dalam Figh bukanlah hukum yang statis, dinamikanya 
berkembang seiring dengan perkembangan masyarakat. Ada kaidah Fiqh al-bukmu yaduru ma'a al-illatibi wujudan wa 'adaman (keberlakuan suatu aturan atau hukum terkait dengan ada atau tidak adanya alsasan). Hukum itu bisa berubah sesuai dengan perubahan illat albukmi (sebab hukum)-nya. Dalam konteks status hukum dan hakhak anak di luar nikah Fiqh klasik secara tegas menyatakan hanya ada hungan perdata dengan ibunya dan keluarga ibunya, karena faktanya si anak dikandung oleh ibu tadi tersebut. Hal ini didasarkan pada keterangan hadits al-waladu lil firasy. Sedangkan dengan ayah tidak adanya hubungan karena tidak adanya bukti yang menunjukkan bahwa dia anaknya, dan tidak ada akad nikah.

Mengutip tulisan Ainur R. Sophiaan dalam majalah Matan PW Muhammadiyah Jatim, edisi 69, April 2012, hal 48 menyebutkan pihak Kementrian Agama merasa bingung mensikapi adanya benturan putusan MK dan MUI. Sebagai aparatur pemerintah, di satu sisi wajib mematuhi segala putusan MK, di sisi lain, Kementrian Agama wajib menjadikan fatwa MUI sebagai bahan pertimbangan dalam mengeluarkan kebijakan, karena MUI representasi ulama yang diakui di Indonesia. Wakil Menteri Agama Nasaruddin menyatakan bahwa di ranah lapangan akan menemui kendala sehingga membutuhkan waktu untuk mensosialisasikannya. Jika demikian kita akan tunduk, tapi bagaimana dengan pencatatan kelahiran anak yang dulu tidak bisa karena orang tuanya tidak memiliki surat nikah.

Menggarisbawahi isi putusan MK mengenai pasal 43 ayat (1) UU No.1/1974, Maka ada 2 (dua) persoalan yang kami anggap penting untuk dibahas, pertama memaknai kata "anak yang lahir di luar perkawinan" dan kedua "pembuktian melalui IPTEK atau alat bukti lain yang dibenarkan hukum" bahwa antara anak dan ayah biologisnya mempunyai hubungan darah. Dalam hal ini, hakim Pengadilan Agama adalah praktisi hukum yang memiliki otoritas untuk menginterpretasikan rumusan pasal tersebut, sekaligus menjalankan proses pembuktian adanya hubungan perdata antara anak yang lahir di luar perkawinan dan ayah biologisnya. Jawaban atas dua permasalahan tersebut diharapkan diperoleh langsung dari para hakim Pengadilan yang memiliki kompetensi menyelesaikan perkara perdata, salah satunya mengenai mengenai perkara 
"Penetapan asal usul anak". Bagi ummat Islam sesuai dengan asas personalitas keislaman seperti yang diatur oleh pasal 2 Undang-Undang Nomor 7 Tahun 1989 Tentang Peradilan Agama, maka yang berhak memutuskan adalah Pengadilan Agama dan Mahkamah Syar'iyah.

Berangkat dari latar belakang masalah tersebut di atas kami bermaksud melakukan penelitian terhadap pendapat para hakim Pengadilan Agama (PA) di Jawa Timur mengenai interpretasi dan pelaksanaan rumusan pasal 43 ayat (1) Undang-Undang Perkawinan Nomor 1 Tahun 1974 yang dimuat dalam amar putusan MK no. 46/PUU-VIII/2010.

\section{Metode Penelitian}

Tulisan ini merupakan hasil penelitian lapangan (Field research) tentang pendapat hakim Pengadilan Agama terhadap status anak di luar perkawinan pasca putusan MK No.46/PUUVIII/2010. Di antara jumlah PA di Kabupaten/ kota di Jawa Timur, peneliti mengambil dua Pengadilan Agama (PA), yaitu PA Bangkalan, dan PA Sidoarjo. Penelitian ini kami laksanakan selama 2 (dua) bulan, yakni bulan Juli sampai dengan Agustus 2012.

Pengumpulan data kami lakukan dengan tehnik wawancara dan dokumentasi. Wawancara kami lakukan dengan cara dialog/tanya jawab kepada para ketua PA, Wakil ketua, ketua/sekretais kepanitraan dan wakilnya, 2 orang hakim (seorang laki-laki dan seorang perempuan) dari PA Bangkalan dan 2 orang hakim (seorang laki-laki dan seorang perempuan) dari PA Sidoarjo dengan menggunakan questioner (soal essay) sebagai instrumen penggalian data, Sedangkan dokumentasi dilakukan dengan cara mengumpulkan dan menelaah dokumen khususnya Putusan MK No 46/PUU-VIII/2010 serta dokumen kepaniteraan dan berkas perkara penetapan itsbat nikah dan asal usul anak, serta dokumen terkait lainnya.

Setelah data terkumpul, analisis data kami lakukan secara diskriptif - verifikatif, yaitu mendiskripsikan data seadanya tentang berbagai pendapat, hakim di PA Bangkalan dan PA Sidoarjo mengenai makna anak yang dilahirkan di luar perkawinan menurut pasal 43 ayat (1) Undang-Undang Nomor 1 Tahun 1974, status 
hukum dan hak keperdataannya serta komentar, pandangan mereka mengenai keberlakuan putusan MK No 46/PUUVIII/2010 dalam penerapan di Pengadilan Agama. Metode ini digunakan untuk menjelaskan pendapat masing-masing hakim tersebut, sehingga diperoleh kesimpulan yang memungkinan terjadi persamaan, perbedaan, spesifikasi dan kesesuaian pendapat para hakim tersebut dengan pendapat para ahli hukum Islam.

\section{Komentar dan Pendapat Hakim Terhadap Putusan MK No. 46/PUU-VIII/2010}

1. Putusan MK Cacat Hukum

Pada hakekatnya, putusan MK No 46/PUU-VIII/2010 Tentang Permohonan Uji Materiil Undang-Undang (yudicial review) pasal 2 ayat (2) dan pasal 43 ayat (1) UU No 1 tahun 1974 terhadap pasal 28B ayat (1) dan ayat (2) serta pasal 28D ayat (1) UUD 1945 yang permohonannya dikabulkan sebagian, yakni pasal 43 ayat (1) UU No 1 Tahun 1974 merupakan kasuistik poligami di bawah tangan antara Mordiono dengan Machicha Mochtar yang berakibat lahirnya anak bernama Muhammad Iqbal Ramadlan. Namun dalam tataran putusan MK sebagai putusan peradilan tingkat pertama dan terakhir, menjadi bersifat general dalam penerapannya. Oleh karenanya, wajar apabila menimbulkan polemik di kalangan masyarakat terutama kalangan ulama dan MUI.

Yang menjadi persoalan sebenarnya dalam kasus ini adalah bagaimana status hukum anak yang lahir dari poligami di bawah tangan. Hal ini tidak secara langsung berkaitan dengan anak yang lahir di luar perkawinan sebagaimana yang dituju oleh pasal 43 ayat (1) UU No 1 tahun 1974. Poligami di bawah tangan tersebut jelas-jelas merupakan pelanggaran pasal 4 dan 5 UU No 1 tahun 1974 mengenai prosedur izin poligami, oleh karena itu tidak akan pernah memenuhi ketentuan pasal 2 ayat (2) UU No 1 tahun 1974 mengenai pencatatan perkawinan. Perkawinan yang melanggar ketentuan ini adalah termasuk perkawinan yang tidak dapat dibenarkan undang-undang sesuai dengan pasal 9 UU No 1 tahun 1974 mengenai larangan 
perkawinan, dalam hal ini adalah poligami tanpa izin Pengadilan (non-procedural).

Model poligami yang demikian merupakan perkawinan yang tidak memiliki kekuatan hukum sesuai ketentuan pasal 56 ayat (3) KHI, artinya perkawinan tidak dapat dibuktikan kebenarannya secara hukum. Maka konsekwensinya seharusnya pihak-pihak yang merasa keberatan berpeluang besar mengajukan permohonan pembatalan perkawinan ke Pengadilan Agama sesuai pasal 71 huruf (a) KHI yang menyatakan "perkawinan dapat dibatalkan apabila seorang suami melakukan poligami tanpa ižin Pengadilan Agama".

Apabila permohonan pembatalan tersebut dapat dibuktikan secara hukum di hadapan sidang pengadilan kemudian pengadilan menjatuhkan putusan dengan amar membatalkan perkawinannya, maka putusan tersebut sesuai dengan ketentuan pasal 28 ayat (2) huruf (a) UU No 1 tahun 1974 yang senada dengan pasal 75 ayat (b) KHI, bahwa putusan tidak berlaku surut terhadap anak yang dilahirkan dari perkawinan tersebut, artinya tidak menghapuskan hubungan nasab dengan kedua orang tuanya.

Persoalannya kemudian, bagaimana apabila ada pihak yang keberatan terhadap status anak yang dilahirkan dari poligami di bawah tangan? Maka dalam hal ini, pembuktiannya dilakukan secara formal, yaitu akta kelahiran. Apabila akta kelahiran tersebut menyebutkan hubungan nasab anak terhadap kedua orang tuanya, maka syarat pokok dari akta kelahiran tersebut harus ada akta nikah kedua orang tuanya. Jika tidak dapat diperoleh, maka status hukum anak sama dengan tidak ada secara hukum. Karenanya, nasab anak tidak dapat dihubungkan kepada ayahnya. Hal ini sesuai dengan pasal 27 UU No 23 tahun 2006 bahwa "pencatatan kelabiran berasaskan kepada peristiwa kelabiran". Apabila orang tuanya tidak dapat menyerahkan bukti perkawinannya, maka yang tertulis di akta kelahiran hanyalah ibunya.

Mengenai pencatatan poligami di bawah tangan, sesuai dengan pasal 44 PP No 9 tahun 1975 merupakan perkawinan yang melanggar prosedur Undang-Undang dan keberadaannya 
tidak dapat ditoleransi. Adapun mengenai status hukum anak yang lahir dari perkawinan tersebut dapat ditempuh melalui permohonan penetapan asal usul anak. Menurut pasal 55 ayat (2) UU No 1 tahun 1974 bahwa "bila akta kelabiran tersebut dalam pasal 5 ayat (1) tidak ada, maka Pengadilan dapat mengeluarkan penetapan asal usul seorang anak setelah diadakan pemeriksaan yang teliti berdasarkan bukti-bukti yang memenubi syarat.

Dalam konteks ini, putusan MK yang ditetapkan atas kasus tersebut merupakan putusan yang penuh polemik, karenanya dikategorikan sebagai putusan yang melanggar undang-undang, putusan yang mandul tidak dapat dieksekusi. Putusan MK yang memberlakukan status hukum anak di luar perkawinan secara general, baik kelahiran anak sebagai akibat perzinaan, sebagai akibat perkawinan poligami dibawah tangan, mengakibatkan bias hukum. Kalaupun putusan MK dipaksakan untuk diberlakukan, sangat tidak adil. Menurut pendapat hakim di PA Bangkalan, yang seharusnya bukan mereview pasal 43 ayat (1) melainkan menambah satu ayat dengan rumusan "membebankan tanggungjawab nafkah terhadap ayah yang menyebabkan anak labir di luar perkawinan".

Putusan MK yang mengabulkan permohonan pemohon, mengandung cacat hukum, karena kasus yang didalilkan pemohon adalah kasus anak yang lahir sebagai akibat perkawinan poligami di bawah tangan, sedangkan yang dimohonkan adalah mereview ketentuan pasal 2 ayat (2) dan pasal 43 ayat (1) UU No 1 tahun 1974. Dalam hal ini, MK mengabulkan review pasal 43 ayat (1) mengenai status hukum anak yang lahir di luar perkawinan. Putusan MK telah menganalogikan anak yang lahir sebagai akibat poligami di bawah tangan dengan anak yang lahir di luar perkawinan, padahal kedua anak tersebut status hukumnya berbeda. ${ }^{2}$

Menurut pendapat ini, pasal 43 ayat (1) UU No 1 tahun 1974 senada dengan pasal 100 KHI, substansinya tidak bertentangan dengan pasal 28B ayat (1) dan ayat (2) UUD 1945,

${ }^{1}$ Abdul Hadi, Wawancara, hakim PA Sidoarjo, 8 Agustus 2012.

2Abdul Majid, Wawancara, hakim PA Bangkalan, 6 Agustus 2012. 
sedangkan putusan MK bertentangan dengan pasal 28B ayat (1) UUD 1945 dan bertentangan dengan syariat islam, oleh karenanya putusan MK yang demikian itu akan selalu mengundang polemik berkepanjangan dalam masyarakat muslim.

2. Putusan MK Menunggu Petunjuk Pelaksanaan

Putusan MK No 46/PUU-VIII/2010 memang tampak memberi jaminan bagi perlindungan hak-hak anak yang lahir di luar perkawinan, karena dengan perubahan redaksi tersebut, anak lahir di luar perkawinan diakui mempunyai hubungan perdata dengan ayahnya dan keluarga ayahnya. Hal ini menggambarkan bahwa hak-hak perdata anak lahir di luar perkawinan telah mendapatkan payung hukum untuk memperoleh perlindungan hukum dari ayah biologisnya serta keluarga dari ayah biologisnya, namun demikian masih terkesan kontradiktif dengan pasal 42 UU No 1 Tahun 1974 mengenai rumusan "anak sah" dan hukum Islam, sehingga rawan konflik di kalangan masyarakat muslim, apalagi MUI sudah menentang keras perubahan pasal tersebut. ${ }^{3}$

Pemberlakuan rumusan baru pasal 43 ayat (1) UU No 1 Tahun 1974 dalam putusan MK tersebut masih sulit, disebabkan bunyi redaksi "anak yang lahir di luar perkawinan" sangat umum pengertiannya sehingga kesulitan apabila diterapkan pada kasus yang konkrit. Oleh karena itu memerlukan aturan tehnis bagaimana pengajuan perkaranya di Pengadilan. Meski putusan MK telah dibacakan sejak bulan Pebruari 2012, hingga kini belum ada peraturan yang mengatur lebih lanjut bagaimana pelaksanaan pasal 43 ayat (1) tersebut. Sebagai hakim yang akan menerapkan perundang-undangan, maka selama belum ada peraturan khusus yang mengatur tentang pelaksanaan pasal 43 ayat (1) UU No 1 Tahun 1974, maka perubahan pasal 43 ayat (1) tersebut dalam putusan MK bakal menjadi putusan "mandul". 4

${ }^{3}$ Baca MUI, makalah: Tanggapan MUI tentang Putusan MK No 46/PUUVIII/2010 Pengujian UU No 1 tahun 1974 tentang Perkawinan, 13 Maret 2010. ${ }^{4}$ Musri, Wawancara, hakim PA Bangkalan, 6 Agustus 2012. 
Pengertian anak yang lahir di luar perkawinan dalam rumusan baru pasal 43 ayat (1) masih sangat umum dan bersifat interpretatif, karena di masyarakat kita, paling tidak ada 3 (tiga) macam kategori anak tersebut, yaitu anak yang lahir dari perkawinan sirri, anak yang lahir dari perselingkuhan, anak yang lahir dari hidup bersama tanpa ikatan perkawinan (samen liven). Guna memperoleh hak-hak keperdataannya ke pengadilan, ketiga macam anak di luar perkawinan tersebut, teknis pengajuan perkaranya berbeda.

Anak yang lahir dari perkawinan sirri pengajuan perkaranya melalui permohonan “ithbat nikah' ke Pengadilan Agama, dan dengan dikabulkannya permohonan ithbat nikah itu, para pihak membawa penetapan Pengadilan Agama kepada KUA setempat agar dapat memperoleh kutipan akta nikah dan selanjutnya dibawa ke kantor catatan sipil, guna mengurus akta kelahiran. Sedangkan untuk anak yang lahir dari hasil perselingkuhan atau anak yang lahir dari hasil hidup bersama (samen liven) tanpa ikatan nikah, maka cara pengajuan perkaranya ke pengadilan tentunya berbeda dengan prosedur beracara bagi anak yang lahir di luar perkawinan. Dalam konteks ini, pendapat kedua menyatakan bahwa putusan MK memerlukan aturan tehnis untuk menerapkannya.

Pada tataran pembuktian hubungan perdata antara anak dengan ayah biologisnya berdasarkan ilmu pengetahuan dan tehnologi dan /atau bukti lain menurut hukum, adalah hal tehnis yang berhubungan dengan persidangan, dan masalah pembuktian di persidangan adalah menyangkut hukum acara, sehingga tentunya berlaku hukum Acara perdata pada umumnya.

3. Putusan MK Hanya Berlaku Secara Terbatas

Putusan MK yang menyatakan bahwa anak yang lahir di luar perkawinan adalah anak yang dilahirkan dalam keadaan kedua orang tuanya tanpa ada ikatan perkawinan yang diakui oleh undang-undang. Untuk kawin sirri atau kawin di bawah tangan selama tidak dapat dibuktikan di Pengadilan tentang keabsahan perkawinannya melalui "ithbat nikah", maka dapat 
dikatakan sebagai "tidak ada ikatan perkawinan". Oleh karena itu, dalam konteks inilah putusan MK No 46/PUU-VIII/2010 tidak dapat diterapkan pada semua jenis hubungan keperdataan anak dan ayah biologisnya. Hubungan keperdataan anak dan ayahnya yang dapat ditoleransi, dibatasi pada hak-hak kebendaan saja, yang meliputi hak memperoleh nafkah, hak memperoleh biaya pendidikan serta biaya hidup lainnya. Sedangkan hak yang berhubungan dengan penasaban anak kepada ayah biologisnya dan akibatnya kepada hak waris, belum dapat ditoleransi sebagai hak yang dapat diperoleh dari ayah biologisnya. Sebab kedua akibat hukum (nasab dan waris) tersebut merupakan hak yang diperoleh anak disebabkan adanya ikatan perkawinan yang sah kedua orang tuanya, sementara anak yang dilahirkan di luar perkawinan, secara nyata kedua orang tuanya tidak pernah ada ikatan perkawinan yang sah, baik yang keabsahannya sejak menikah di KUA, maupun yang keabsahannya diithbatkan oleh Pengadilan Agama yang berwenang. Dalam konteks anak lahir di luar perkawinan tersebut, kedua prosedur keabsahan perkawinan seperti yang dikemukakan tidak pernah mereka tempuh. ${ }^{5}$

4. Putusan MK Berlaku Secara Mutlak

Sesuai dengan putusan MK No 46/PUU-VIII/2010 yang mengabulkan permohonan uji materiil atas pasal 43 ayat (1) UU No. 1 Tahun 1974 merupakan putusan yang telah memiliki kekuatan hukum untuk diberlakukan, karena Mahkamah Konstitusi (MK) merupakan peradilan tingkat pertama sekaligus peradilan tingkat terakhir sehingga produk hukum yang dihasilkan tidak dapat dinaikbandingkan atau dikasasikan oleh mereka yang keberatan dengan putusan MK tersebut. Dalam konteks ini putusan MK berlaku tanpa syarat, sebagai produk hukum yang berlaku secara otomatis tanpa menunggu tenis pelaksanaannya, misalnya perundang-undangan di tingkat bawahnya. Hal ini berbeda dengan pemberlakuan sebuah perundang-undangan produk legislasi hukum, di mana

${ }^{5}$ Siti Muarofah Sa'adah, Wawancara, hakim PA Sidoarjo, tanggal 9 Agustus 2012. 
keberlakuannya secara efektif akan membutuhkan perangkat perundang-undangan di bawahnya, seperti Peraturan Perundang-undangan (PP) dan seterusnya ke bawah.

Dengan demikian, status hukum anak yang dilahirkan di luar perkawinan, perlu dibuktikan dulu hubungan darahnya dengan laki-laki sebagai ayah biologisnya melalui pembuktian alat tehnologi atau alat bukti lain yang dibenarkan oleh hukum mempunyai hubungan darah antara keduanya. Jika benar-benar terbukti di persidangan maka akan berlakulah ketentuan baru pasal 43 ayat (1) UU No 1 tahun 1974 seperti yang dikehendaki oleh putusan MK No 46/PUU-VIII/2010. Sebagai konsekwensi hukumnya, anak yang dilahirkan di luar perkawinan akan mempunyai hak-hak keperdataan seperti halnya hak-hak anak yang lahir dalam atau akibat perkawinan kedua orang tuanya, baik yang berkaitan dengan hak-hak kebendaan, nafkah, biaya pendidikan, warisan, nasab dan perwaliannya. $^{6}$

Meskipun demikian, menurut pendapat ini, pengakuan hak-hak keperdataan anak yang lahir di luar perkawinan, tidak serta merta dapat diperoleh selama belum ada upaya hukum yang dapat memastikan kebenaran adanya hubungan darah antara anak dengan ayah biologisnya. Upaya hukum dimaksud adalah proses pembuktian di pengadilan yang didasarkan pada ilmu pengetahuan dan tehnologi, seperti tes DNA (deocyribonucleic acid) atau alat bukti lain yang menurut hukum dapat dibenarkan, misalnya berupa pengakuan. Dengan demikian, maka kasus anak yang lahir di luar perkawinan berpeluang untuk diproses pengadilan melalui pengajuan perkara permohonan atau gugatan "asal-usul anak" di pengadilan yang berwenang. Apabila permohonan atau gugatannya dikabulkan pengadilan, maka secara yuridis hak-hak keperdataan anak yang lahir di luar perkawinan dapat diperoleh secara penuh, yaitu hak alimentasi, hak nafkah, hak biaya pendidikan, hak penasaban kepada ayah, hak ahli waris, serta hak perwalian nikah jika anak perempuan.

${ }^{6}$ Abd. Hadi, Wawancara, hakim PA Sidoarjo, tanggal 3 Agustus 2012. 


\section{Argumentasi Gugatan Putusan MK No 46/PUU-VIII/2010}

Putusan Mahkamah Konstitusi (MK) No 46/PUUVIII/2010 yang dibacakan pada sidang putusan tanggal 17 Pebruari 2012, merupakan suatu putusan monumental pada ranah hukum keluarga atas permohonan pengujian Undang-Undang Perkawinan No 1 tahun 1974 terhadap Undang-Undang Dasar Negara Republik Indonesia tahun 1945 yang diajukan Machicha Mochtar yang telah menikah "sirri" dengan Moerdiono (mantan menteri RI). Machicha menuntut agar pasal 2 ayat (2) yang mengatur masalah pencatatan perkawinan dan pasal 43 ayat (1) yang mengatur status keperdataan anak luar kawin dinyatakan bertentangan dengan konstitusi dan harus dinyatakan tidak mempunyai kekuatan hukum dengan segala akibatnya.

Dalam keterangan duduk perkaranya disebutkan sebagai berikut: Pertama, bahwa pasal 2 ayat (2) UU No 1 tahun 1974 tentang Perkawinan menyatakan "Tiap-tiap perkawinan dicatat menurut peraturan perundang-undangan yang berlaku". Dengan berlakunya pasal 2 ayat (2) undang-undang perkawinan ini, pemohon menyatakan bahwa hak-hak konstitusionalnya sebagai warga negara Indonesia yang dijamin oleh pasal 28B Ayat (1) dana (2) serta pasal 28 D ayat (1) UUD 1945 telah dirugikan. Pasal 28B ayat (1) UUD 1945 menyatakan "setiap orang berbak membentuk keluarga dan melanjutkan keturunan melalui perkawinan yang sab". Pasal 28B ayat (2) UUD 1945 menyatakan "setiap anak berbak atas kelangsungan bidup, tumbuh dan berkembang serta berhak atas perlindungan dari kekerasan dan diskriminasi".

Selanjutnya pemohon menyatakan, bahwa kedua pasal dalam UUD 1945 tersebut melahirkan dua norma konstitusi, yaitu pemohon merupakan warga negara Indonesia, memiliki hak setara dengan warga negara Indonesia lainnya dalam membentuk keluarga dan melaksanakan perkawinan tanpa dibedakan dan wajib diperlakukan sama di hadapan hukum dan anak pemohon juga memiliki hak atas status hukumnya dan diperlakukan sama di hadapan hukum.

${ }^{7}$ Lihat Putusan MK No 46/PUU-VIII/2010, 4. 
Kedua, pasal 43 ayat (1) UU No 1 Tahun 1974 Tentang Perkawinan menyatakan "Anak yang dilabirkan di luar perkawinan hanya mempunyai bubungan perdata dengan ibunya dan keluarga ibunya". Menurut pihak pemohon, dengan berlakunya pasal 43 ayat (1) ini, maka hak-hak konstitusional pemohon selaku ibunya dan anaknya untuk mendapatkan pengesahan atas pernikahannya serta status hukum anaknya yang dijamin oleh pasal 28 B ayat (1) dan (2) serta pasal 28 D ayat (1) UUD 1945 telah dirugikan. Pasal 28 D ayat (1) UUD 1945 menyatakan: "Setiap orang berbak atas pengakuan, jaminan, perlindungan, dan kepastian bukum yang adil serta perlakuan yang sama di badapan bukum".

Merujuk pada ketentuan pasal 28 D ayat (1) UUD 1945, maka pasal 2 ayat (2) dan pasal 43 ayat (1) UU No 1 tahun 1974 tentang Perkawinan, tidaklah senafas dan sejalan serta telah merugikan hak konstitusional pemohon dan anaknya. Berdasar semua uraian tersebut, jelas menunjukkan, bahwa pemohon memiliki kedudukan hukum (legal standing) untuk bertindak sebagai pemohon dalam permohonan uji materiil undang-undang. ${ }^{8}$

Terkait dengan permohonan uji materiil UU No. 1 Tahun 1974 dalam putusan MK No 46/PUU-VIII/2010 di atas, meskipun permohonannya tertuju pada pasal 2 ayat (2) dan pasal 43 ayat (1) UU No 1 tahun 1974, namun kajian teoritis penelitian ini lebih terfokus pada pasal 43 ayat (1) UU No. 1 Tahun 1974, salah satu pasal krusial dalam hukum keluarga Indonesia yang mengatur status hak keperdataan anak di luar perkawinan yang menurut undang-undang hanya memiliki hubungan perdata dengan ibunya dan keluarga ibunya. Aturan ini oleh pemohon dirasa tidak adil bagi kepentingan anak, sebab seorang anak yang tidak berbuat dosa harus menanggung kesalahan yang diperbuat oleh orang tuanya, padahal pria yang menyebabkan kelahiran anak tersebut terbebas dari kewajiban hukum untuk memelihara, mendidik, memberikan perlindungan yang seharusnya diberikan orang tua kepada anak. Tidak ada seorang anak lahir di muka bumi ini dipersalahkan dan diperlakukan diskriminatif karena cara pernikahan yang ditempuh orang tuanya berbeda dengan ketentuan

${ }^{8}$ Lihat Putusan MK No 46/PUU-VIII/2010, 6. 
perundang- undangan, yakni telah memenuhi norma agama, namun belum tercatatkan di kantor yang berwenang. Dan anak yang dilahirkan seharusnya diakui oleh hukum sebagai anak sah dan wajib diperlakukan sama di hadapan hukum.

\section{Amar Putusan MK Mengenai Pasal 43 Ayat (1) UU No. 1 Tahun 1974}

Pada dasarnya, membahas anak di luar perkawinan menurut konteks hukum positif di Indonesia adalah membahas rumusan asal pasal 43 ayat (1) UU No 1 Tahun 1974 Tentang Perkawinan sebelum putusan MK No 46/PUU-VIII/2010 yang berbunyi: "Anak yang dilabirkan di luar perkawinan hanya mempunyai bubungan perdata dengan ibunya dan keluarga ibunya". Pasal tersebut merupakan salah satu pasal yang dikabulkan permohonan uji materiilnya oleh MK melalui putusan No. 46/PUU-VIII/2010. Keputusan ini merupakan masalah krusial dalam tatanan hukum keluarga Indonesia karena terkait dengan status hak keperdataan anak yang lahir di luar perkawinan, yang menurut undang-undang perkawinan di Indonesia selama ini hanya memiliki hubungan perdata dengan keluarga ibunya. Dengan melakukan pemahaman secara " $a$ contrario" terhadap pengertian anak sah sebagaimana tercantum dalam pasal 42 UU No 1 Tahun 1974, maka anak luar kawin (anak tidak sah) seperti yang diatur oleh pasal 43 ayat (1) dapat diartikan sebagai anak yang tidak dilahirkan dalam atau sebagai akibat perkawinan yang sah. Pada tataran praktik, misalnya dapat dilihat pada anak yang lahir akibat hubungan seks bebas dan perkosaan.

Selain peniadaan hubungan perdata anak luar kawin dengan ayah dan keluarga ayahnya, anak luar kawin terkadang masih mendapat stigma negatif masyarakat. Istilah anak haram dan lainnya yang sering disematkan oleh sebagian orang kepada anak luar kawin, dinilai sebagai sangsi sosial tanpa dasar karena sang anak tidak bersalah dan tidak pernah berharap dilahirkan dari orang tua yang tidak memiliki ikatan perkawinan. Dalam konteks “ membela hak-hak keperdataan anak", MK telah memberikan putusan yang monumental dalam ranah hukum keluarga Indonesia,

${ }^{9}$ Himpunan Peraturan Perundang-Undangan Perkawinan Indonesia, 2009, 19. 
yakni merubah secara mendasar rumusan pasal 43 ayat (1) UU No 1 Tahun 1974, sebagaimana tersebut dalam amar putusan di bawah ini:

Pertama, "pasal 43 ayat (1) UU No 1 tahun 1974 tentang Perkawinan (Lembaran Negara Republik Indonesia tahun 1974 Nomor 1, Tambahan Lembaran Negara Republik Indonesia Nomor 3019) yang menyatakan, "Anak yang labir di luar perkawinan hanya mempunyai hubungan perdata dengan ibu dan keluarga ibunya" bertentangan dengan Undang-Undang Dasar tahun 1945 sepanjang dimaknai menghilangkan hubungan perdata anak dengan laki-laki yang dapat dibuktikan berdasarkan ilmu pengetahuan dan tehnologi dan/atau alat bukti lain menurut hukum ternyata mempunyai hubungan darah sebagai ayahnya".

Kedua, "pasal 43 ayat (1) UU No 1 Tahun 1974 Tentang Perkawinan (Lembaran Negara Republik Indonesia Tahun 1974 Nomor 1, Tambahan Lembaran Negara Republik Indonesia Nomor 3019) yang menyatakan "Anak yang dilabirkan di luar perkawinan banya mempunyai bubungan perdata dengan ibunya dan keluarga ibunya", tidak memiliki kekuatan hukum mengikat sepanjang dimaknai menghilangkan hubungan perdata dengan lakilaki yang dapat dibuktikan berdasarkan ilmu pengetahuan dan tehnologi dan/atau alat bukti lain menurut hukum ternyata mempunyai hubungan darah sebagai ayahnya, sehingga ayat tersebut harus dibaca, "Anak yang dilabirkan di luar perkawinan mempunyai bubungan perdata dengan ibunya dan keluarga ibunya serta lakilaki sebagai ayabnya yang dapat dibuktikan berdasarkan ilmu pengetabuan dan tehnologi dan/atan alat bukti lain menurut bukum mempunyai bubungan darah, termasuk bubungan perdata dengan keluarga ayahnya". ${ }^{10}$

\section{Pertimbangan Hukum Putusan MK No 46/PUU-VIII/2010}

Adapun pertimbangan hukum $\mathrm{MK}$ atas pengujian materiil pasal 43 ayat (1) UU No 1 Ttahun 1974 Tentang Perkawinan, menyebutkan bahwa pokok permasalahan hukum mengenai anak yang dilahirkan di luar perkawinan adalah mengenai makna hukum (legal meaning) frasa "yang dilabirkan di luar perkawinan". Untuk

10Putusan MK No,46/PUU-VIII/2010, 37. 
memperoleh jawaban dalam perspektif yang lebih luas, perlu dijawab pula permasalahan terkait, yaitu permasalahan tentang sahnya anak.

Pertama, secara alamiah, tidaklah mungkin seorang perempuan hamil tanpa terjadinya pertemuan antara ovum dengan spermatozoa, baik melalui hubungan seksual (coitus) maupun melalui cara lain berdasarkan perkembangan teknologi yang menyebabkan terjadinya pembuahan. Oleh karena itu, tidak tepat dan tidak adil manakala hukum menetapkan bahwa anak yang lahir dari suatu kehamilan karena hubungan seks di luar perkawinan hanya memiliki hubungan dengan perempuan tersebut sebagai ibunya. Adalah tidak tepat dan tidak adil pula jika hukum membebaskan laki-laki yang melakukan hubungan seksual yang menyebabkan terjadinya kehamilan dan kelahiran anak tersebut dari tanggung jawabnya sebagai seorang bapak dan bersamaan dengan itu hukum meniadakan hak-hak anak terhadap lelaki tersebut sebagai bapaknya. Lebih-lebih manakala berdasarkan perkembangan tehnologi yang ada, memungkinkan dapat dibuktikan bahwa seorang anak itu merupakan anak dari laki-laki tertentu.

Kedua, akibat hukum dari peristiwa hukum kelahiran karena kehamilan, yang didahului dengan hubungan seksual antara seorang perempuan dengan seorang laki-bertimbal balik, yang subyek hukumnya meliputi anak, ibu, dan bapak. Berdasarkan uraian di atas, hubungan anak dengan seorang laki-laki sebagai bapak tidak semata-mata karena adanya ikatan perkawinan, akan tetapi dapat juga didasarkan pada pembuktian adanya hubungan darah antara anak dengan laki-laki tersebut sebagai bapak. Dengan demikian terlepas dari soal prosedur/ administrasi perkawinannya, anak yang dilahirkan harus mendapatkan perlindungan hukum. Jika tidak demikian, maka yang dirugikan adalah anak yang dilahirkan di luar perkawinan, padahal anak tersebut tidak berdosa karena kelahirannya di luar kehendaknya. Anak yang dilahirkan tanpa memiliki kejelasan status ayah seringkali mendapatkan perlakuan yang tidak adil dan stigma di tengah-tengah masyarakat. Hukum harus memberi perlindungan dan kepastian hukum yang adil terhadap status seorang anak yang dilahirkan dan hak-hak yang ada 
padanya, termasuk terhadap anak yang dilahirkan meskipun keabsahan perkawinannya masih dipersengketakan.

Ketiga, menimbang bahwa berdasarkan uraian tersebut di atas maka pasal 43 ayat (1) UU No 1 Tahun 1974 yang menyatakan, "Anak yang dilabirkan di luar perkawinan hanya mempunyai bubungan perdata dengan ibunya dan keluarga ibunya" harus dibaca, "Anak yang labir diluar perkawinan mempunyai bubungan perdata dengan ibunya dan keluarga ibunya serta laki-laki sebagai ayahnya yang dapat dibuktikan berdasarkan ilmu pengetabuan dan tehnologi dan/atau alat bukti lain menurut bukum mempunyai bubungan darah, termasuk bubungan perdata dengan keluarga ayahnya".

Keempat, menimbang bahwa berdasarkan seluruh pertimbangan hukum di atas, pasal 43 ayat (1) UU No 1 tahun 1974 yang menyatakan "Anak yang labir di luar perkawinan banya mempunyai bubungan perdata dengan ibunya dan keluarga ibunya" adalah bertentangan dengan UUD 1945 secara bersyarat (conditionally unconstitutional) yakni inkonstitusional sepanjang ayat tersebut dimaknai menghilangkan hubungan perdata dengan laki-laki yang dapat dibuktikan berdasarkan ilmu pengetahuan dan tehnologi dan/ atau alat bukti lain menurut hukum mempunyai hubungan darah sebagai ayahnya. ${ }^{11}$

\section{Pengertian Anak Lahir di Luar Perkawinan Menurut Pendapat Hakim PA Bangkalan dan PA Sidoarjo}

Perubahan atas ketentuan pasal 43 ayat (1) UU No 1 Tahun 1974 oleh rumusan baru dalam Putusan MK No. 46/PUUVIII/2010 di atas telah mengakibatkan berbagai komentar, pandangan dan pendapat. Sudah barang tentu dalam penelitian ini yang dimaksudkan adalah pandapat, pandangan, dan komentar para hakim Pengadilan Agama yang akan menerapkan dan menginterpretasikan ketentuan tersebut sebagai bagian dari sumber hukum atas putusan-putusan perkara keabsahan perkawinan serta akibat hukumnya terhadap status hukum anak yang dilahirkan dan hak-hak keperdataannya, maupun perkara keabsahan anak berkaitan dengan asal-usul dan hak-hak

11Putusan MK No 46/PUU-VIII/2010, 35-36. 
keperdataannya. Sehubungan dengan hal tersebut di atas, berikut ini kami sampaikan pendapat sebagian hakim di PA Bangkalan dan PA Sidoarjo mengenai pengertian anak yang lahir di luar perkawinan. "Anak yang lahir di luar perkawinan" dalam pasal 43 ayat (1) UU No. 1 Tahun 1974 yang dikuatkan rumusannya oleh pasal 100 Kompilasi Hukum Islam (KHI), bila dikaitkan dengan fakta di masyarakat, memiliki banyak arti tergantung pada konteks keadaan anak di saat dia dilahirkan. Beberapa pengertian yang termasuk anak lahir di luar perkawinan dapat dikemukakan sebagai berikut:

1. Anak yang dilahirkan oleh seorang perempuan yang tidak memiliki ikatan perkawinan yang sah dengan laki-laki yang menghamilinya.

2. Anak yang dilahirkan di saat orang tuanya dalam perkawinan sirri (sudah terpenuhi syarat rukun secara Islam namun belum tercatat di KUA).

3. Anak yang dilahirkan dari hasil perselingkuhan (baik ibu si anak terikat perkawinan atau tidak).

4. Anak yang dilahirkan dari hasil hidup bersama (samen liven) atau kumpul kebo.

5. Anak yang dilahirkan oleh perempuan yang kehamilannya akibat korban perkosaan (oleh seorang laki-laki atau lebih).

6. Anak yang dilahirkan oleh istri yang dili'an (anaknya diingkari) oleh suaminya.

7. Anak yang dilahirkan oleh perempuan, yang kehamilannya akibat salah orang/ salah sangka (disangka istrinya ternyata bukan).

8. Anak yang dilahirkan oleh perempuan yang kehamilannya akibat perkawinan yang dilarang/ diharamkan (baik bersifat sementara atau selamanya).

9. Anak yang dilahirkan dari hasil hubungan seks suka sama suka atau transaksi prostitusi. ${ }^{12}$

${ }^{12}$ Musri dan Abdul masjid, Wawancara, Hakim PA Bangkalan, 7 agustus 2012, dan Siti Muarofah Sa'adah dan Abdul hadi, Wawancara , hakim PA Sidoarjo, 9 Agustus 2012. 
Sembilan macam keadaan anak yang lahir di luar perkawinan tersebut masing-masing memiliki status hukum yang berbeda dan akibat hukum mengenai hak-hak keperdataannya pun berbeda pula. Dalam hal ini, hakim memiliki kewenangan untuk menggali fakta hukum secara benar, jeli, dan rinci, terurai satu demi satu agar menjadi jelas bagaimana keadaan yang sebenarnya di saat anak tersebut dilahirkan. Terhadap kesembilan pengertian anak yang lahir di luar perkawinan tersebut, para hakim berpendapat bahwa status hukum anak tersebut adalah sebagai berikut:

Pertama, anak yang dilahirkan di luar ikatan perkawinan/tanpa nikah, status hukum anak tersebut dipandang sebagai kelompok anak hasil perzinahan. Implikasi hukumnya, anak hanya memiliki hubungan hukum dengan ibunya dan keluarga ibunya. Kedua, anak yang dilahirkan pada saat orang tuanya telah melakukan kawin sirri (belum tercatatkan di KUA), maka status hukum anak tersebut dapat diakui sebagai anak sah apabila kedua orang tuanya mengajukan permohonan itsbat nikah (pengesahan nikah) kepada PA yang dikabulkan permohonannnya melalui penetapan itsbat nikah. Sebagai implikasinya, anak memiliki hubungan hukum dengan kedua orang tuanya (ayah dan ibunya).

Ketiga, anak yang lahir dari hasil perselingkuhan, memiliki peluang diakui sebagai anak sah apabila ibu kandung si anak yang sedang/masih terikat perkawinan dan suaminya, tidak mengingkari kelahiran anak sebagai anaknya. Namun apabila ibu kandung si anak tidak terikat perkawinan, maka status anaknya dipandang sebagai anak hasil perzinahan. Karenanya, anak hanya memiliki hubungan hukum dengan ibu dan keluarga ibunya. Keempat, anak yang dilahirkan dari hasil hidup bersama (samen liven) atau kumpul kebo, maka status hukum anaknya dipandang sebagai anak hasil perzinahan. Anak yang dilahirkan diakui hanya memiliki hubungan dengan ibunya saja.

Kelima, anak yang lahir sebagai akibat korban perkosaan oleh seorang laki-laki atau lebih, status hukum anaknya dipandang sebagai anak hasil perzinahan yang diakui hanya memiliki hubungan hukum dengan ibu dan keluarga ibunya. Keenam, anak yang dilahirkan oleh istri yang dili'an (anaknya diinkari) suaminya. Anak yang tidak diakui sebagai anak kandung oleh suami dari 
perempuan yang melahirkan anak tersebut, dipandang sebagai anak hasil perzinahan istri dengan laki-laki lain. Anak diakui hanya memiliki hubungan hukum dengan ibu dan keluarga ibunya, anak terputus nasabnya dengan suami ibunya, meskipun anak tersebut kenyatannya dilahirkan dalam ikatan perkawinan kedua orang tuanya.

Ketujuh, anak yang dilahirkan dari kehamilan akibat salah orang/ salah sangka (dikira istrinya ternyata bukan). Anak yang demikian itu masuk kategori anak syubhat, apabila diakui oleh ayah syubhatnya, nasabnya dapat dihubungkan kepadanya. Kedelapan, anak yang dilahirkan dari kehamilan akibat perkawinan dengan mahram yang bersifat sementara maupun selamanya. Seperti menikah dengan saudara kandung atau sepersusuan, maka anak ini dikategorikan sebagai anak hasil perzinahan. Si anak hanya memiliki hubungan hukum dengan ibu dan keluarga ibunya. Kesembilan, anak yang dilahirkan akibat hubungan seksual suka sama suka atau transaksi prostitusi. Anak demikian, jelas-jelas sebagai hasil perzinahan. Oleh karenanya, hanya memiliki hubungan hukum dengan ibu dan keluarga ibunya.

\section{Akibat Hukum Hak Keperdataan Anak Lahir Luar Kawin}

Ketentuan pasal 43 ayat (1) UU No 1 tahun 1974 tentang Perkawinan yang menyatakan bahwa status hukum anak yang lahir di luar perkawinan hanya memiliki hubungan perdata dengan ibu dan keluarga ibunya serta ketentuan pasal 100 Kompilasi Hukum Islam (KHI) yang menyebutkan anak luar kawin hanya memiliki hubungan nasab dengan ibu dan keluarga ibunya, membawa implikasi terhadap diperolehnya hak-hak keperdataan anak dari ibunya dan keluarga ibunya, meliputi:

1. Hak memperoleh hubungan nasab (keturunan)

2. Hak memperoleh nafkah (biaya hidup sehari-hari).

3. Hak memperoleh pendidikan dan biayanya.

4. Hak memperoleh hadanah (perawatan, pengasuhan).

5. Hak memperoleh warisan. ${ }^{13}$

${ }^{13}$ Musri, Wawancara, hakim PA Bangkalan, 7 Agustus 2012. Abdul Hadi, Wawancara, hakim PA Sidoarjo, 3 Agustus 2012. 
Dengan memperhatikan uraian berbagai macam pengertian anak lahir di luar perkawinan di atas, anak yang status hukumnya termasuk kategori lahir di luar perkawinan, oleh UU No 1 Tahun 1974 dan Kompilasi Hukum Islam (KHI), selama ini mereka diakui hanya memiliki hak-hak keperdataan meliputi nasab, nafkah, hadanah, pendidikan, dan warisan dari ibu dan keluarga ibunya saja, sedangkan kepada ayah (suami ibunya) anak tidak memperolehnya.

Sesuai dengan rumusan pasal 43 ayat (1) UU No 1 Tahun 1974, maka anak hanya memiliki "hubungan perdata dengan ibu dan keluarga ibunya" demikian juga dalam pasal $100 \mathrm{KHI}$ maka anak hanya memiliki "hubungan nasab dengan ibu dan keluarga ibunya”. Oleh karenanya, anak yang lahir di luar perkawinan, tidak memiliki hubungan perdata dengan ayahnya, dalam arti tidak mempunyai hubungan nasab yang dilindungi oleh hukum, sehingga hak-hak keperdataan anak seperti hak nafkah, hak atas biaya pendidikan, pemeliharaan, hak atas akta kelahiran, hak waris dan hak lain-lain dari ayah biologisnya, tidak mendapatkan perlindungan hukum. Anak tersebut hanya mendapatkan perlindungan hukum atas hak-hak keperdataannya dari ibu dan keluarga ibunya saja. ${ }^{14}$

Sedangkan untuk anak yang dilahirkan dari hasil pernikahan sirri (sudah memenuhi syarat-rukun keagamaan Islam namun belum tercatat di KUA), diperlukan upaya hukum dalam bentuk permohonan ithbat nikah (pengesahan nikah) oleh pemohon (suami-istri) atas perkawinan sirrinya itu kepada Pengadilan Agama yang berwenang. Apabila kemudian dalam putusan perkaranya sesudah melalui proses pembuktian di persidangan, hakim mengabulkan permohonannya, maka kepada yang bersangkutan diberikan surat penetapan itsbat nikah dan selanjutnya dilaporkan kepada kantor pencatat nikah yang berwenang dalam hal ini adalah Kantor Urusan Agama (KUA) setempat guna memperoleh kutipan akta nikah (baca: surat nikah). Melalui prosedur yang demikian itu, status keperdataan "anak yang lahir di luar perkawinan" akan memperoleh perlindungan hukum sebagai anak yang memiliki hak-

${ }^{14}$ Musri, Wawancara, hakim PA Bangkalan, 7 Agustus 2012. Siti Muarofah Sa'adah, Wawancara, hakim PA Sidoarjo, 3 Agustus 2012. 
hak keperdataan sebanding dengan anak yang dilahirkan dalam atau akibat perkawinan sah.

Membahas perkawinan sirri, pada kenyataannya di masyarakat, perkawinan tersebut tidak hanya terjadi pada perkawinan monogami sirri saja, namun juga bisa terjadi pada perkawinan poligami sirri. Kedua model perkawinan tersebut berakibat pada kelahiran anak yang dapat dikategorikan sebagai "anak yang lahir di luar perkawinan". Berbeda dengan ithbat nikah pada monogami sirri yang bersifat voluntair atas permohonan kedua suami istri, dengan produknya berupa penetapan dan keduanya secara bersama-sama atau masing-masing dapat melakukan upaya hukum kasasi. Maka pada poligami sirri, permohonan ithbat nikahnya diajukan oleh salah seorang dari suami istri ke Pengadilan Agama (PA) secara kontentius. Dalam hal ini, istri sebagai pemohon dan suami bersama istri sah terdahulu sebagai termohon sehingga produk hukumnya berupa putusan. Karenanya, terhadap putusan tersebut, dapat diajukan upaya hukum banding dan kasasi. Namun apabila pemohon tidak mau memasukkan istri terdahulu sebagai pihak termohon, permohonan tersebut akan dinyatakan tidak dapat diterima. Demikianlah dinamika permohonan perkara ithbat nikah di pengadilan Agama, khususnya di PA Sidoarjo. Problem tersebut dapat teratasi, karena saran hakim agar pemohon mau mengikuti ketentuan perundangan yang berlaku.

Adapun mengenai implikasi hukum terhadap hak keperdataan anak yang lahir dari perkawinan sirri, para hakim umumnya menyetujui pemberlakuan hak-hak tersebut di atas sesudah perkawinan orang tuanya mendapatkan penetapan atau putusan ithbat nikah dari Pengadilan Agama (PA). Prinsipnya, pengakuan status hukum anak yang dilahirkan di luar perkawinan (karena kawin sirri) biasanya akan dikabulkan apabila perkawinan kedua orang tuanya terbukti di persidangan telah memenuhi syaratrukun perkawinan menurut agama Islam. Sekalipun demikian, apabila dalam pemeriksaan persidangan hakim masih meragukan keabsahan perkawinannya, maka kedua pemohon diminta datang ke KUA yang berwenang untuk menikah dulu. Selanjutnya dengan

${ }^{15}$ Siti Muarofah Sa'adah, Wawancara, hakim PA Sidoarjo, 3 Agustus 2012. 
akta nikah yang diperoleh dari KUA itu, suami-istri mengajukan gugatan perkara "asal-usul anak". ${ }^{16}$

Berbeda dengan kasus anak yang lahir dari perkawinan sirri, maka dimungkinkan kelahiran seorang anak terjadi akibat salah orang/salah sangka mengenai diri seseorang yang dikira istrinya, demikian juga anak yang lahir sebagai akibat perkawinan yang dilarang (baca: karena fasid nikah). Anak yang dilahirkan dengan dua macam latar belakang kehamilan ibunya tersebut, maka status hukum anak dapat diakui memiliki hubungan perdata dengan ayah biologisnya selama ia tidak menolak bahwa anak tersebut adalah benihnya, sehingga nasab anak dapat dihubungkan kepada ayahnya. ${ }^{17}$

Di luar keterangan di atas, masih terdapat pula jenis anak yang dilahirkan di luar perkawinan yang kehamilannya akibat perselingkuhan, akibat hidup bersama (samen liven), dan akibat hubungan seksual suka sama suka atau transaksi prostitusi, dan akibat korban perkosaan oleh seorang laki-laki atau lebih, status hukum anak tersebut semata-mata dihubungkan kepada ibunya dan keluarga ibunya. Dengan demikian maka hak-hak keperdataan anak mengikuti hukum yang berlaku, yaitu hak-haknya diperoleh dari ibu dan keluarga ibunya. Status anak dalam konteks ini, termasuk dalam kelompok anak hasil perzinahan, meskipun sebenarnya, anak tidak ikut menanggung dosa kedua orang tua biologisnya. ${ }^{18}$

\section{Kesimpulan}

Dalam konteks ini penulis telah menghimpun pendapat para hakim di PA Bangkalan dan PA Sidoarjo mengenai status anak yang lahir di luar perkawinan pasca putusan MK No 46/PUUVIII/2010, sebagaimana tersebut di bawah ini:

Pertama, anak yang dilahirkan di luar perkawinan meliputi: anak lahir dari perempuan yang tidak terikat perkawinan dengan laki-laki yang menghamili, anak lahir hasil perkawinan sirri atau di bawah tangan, anak lahir dari perselingkuhan baik perempuan

16Mat Busiril, Wawancara, Wakil panitera PA Sidoarjo, 30 Juli 2012.

${ }^{17}$ Abdul Majid, Wawancara, hakim PA Bangkalan, 6 Agustus 2012.

${ }^{18}$ Abdul Majid, Wawancara, hakim PA Bangkalan, 6 Agustus 2012. 
terikat perkawinan atau tidak, anak lahir dari hasil hidup bersama (samen liven), anak lahir akibat diperkosa oleh seorang laki-laki atau lebih, anak lahir yang diingkari (dili'an) ayahnya, anak lahir akibat hubungan seks salah orang/ salah sangka, anak lahir akibat perkawinan yang fasid batal, dan dimungkinkan anak lahir dari ibu pengganti (surrogate mother).

Kedua, status hukum anak lahir di luar perkawinan masih dipandang sebagai anak yang hanya memiliki hubungan perdata dengan ibunya dan keluarga ibunya selama tidak dapat membuktikan telah terjadi perkawinan antara ibu dan ayah biologisnya. Hubungan perdata yang dimaksud meliputi hak-hak materiil (nafkah, biaya hidup, warisan) maupun immaterial (hubungan nasab dan perwalian).

Ketiga, para hakim PA memiliki pendapat yang berbeda terhadap putusan MK No 46/PUU-VIII/2010 yang mengatur status hukum anak yang dilahirkan di luar perkawinan. Ada empat macam pandangan: putusan MK cacat yuridis, putusan MK perlu pengaturan baru, putusan MK berlaku terbatas pada hak perdata anak yang bersifat materiil, putusan MK mutlak berlaku karena merupakan putusan perkara konstitusi tingkat pertama dan terakhir. Karenanya berimplikasi pada hubungan perdata anak selain dengan ibunya juga dengan ayahnya berdasarkan ilmu pengetahuan dan tehnologi dan/atau bukti lain yang dibenarkan oleh hukum memiliki hubungan darah antara anak dengan ayah biologisnya.

\section{Daftar Pustaka}

MUI, “Tanggapan MUI tentang Putusan MK No 46/PUUVIII/2010 Pengujian UU No 1 tahun 1974 tentang Perkawinan", Makalah, 13 Maret 2010.

Himpunan Peraturan Perundang-Undangan Perkawinan Indonesia, 2009.

Putusan MK No,46/PUU-VIII/2010. 